\title{
THE IMPACT OF INDUSTRY 4.0 ON EDUCATION CONTENTS
}

\author{
Adriana GRENČÍKOVÁ (1) ${ }^{1}$, Marcel KORDOŠ ${ }^{2}{ }^{2}$, Valentinas NAVICKAS® ${ }^{3 *}$ \\ ${ }^{1,3}$ Department of Personnel Management and Human Resources, Faculty of Social and Economic Relations, \\ Alexander Dubcek University in Trencin, Trenčin, Slovakia \\ ${ }^{2}$ Department of Public Administration and Regional Economy, Faculty of Social and Economic Relations, \\ Alexander Dubcek University in Trencin, Trenčin, Slovakia
}

Received 14 July 2020; accepted 13 December 2020

\begin{abstract}
New jobs will be created because of the Industry 4.0 concept implementation needs, employers will require new, especially digital skills and abilities from their employees. There is a need to change teaching and educational techniques in all types of schools, and instead of being specialized narrowly in one area, education should focus on a much broader overview, as people need to be educated in systemic and interdisciplinary thinking at all types of schools, including nontechnical ones. The main goal of the study is to identify areas on which the content of education should focused on in the future in terms to Industry 4.0. As research methods, a questionnaire survey was conducted in Slovak companies during the period of February - June 2019 along with statistical methods. The survey was carried out by random selection, 350 companies were contacted with a return of 220 responses. The research outcomes declare that changes in workforce qualification structure related to the Industry 4.0 concept implementation should have a positive effect on increasing the competitiveness of companies and increasing production effectivity. Based on the results it is proposed the expected positive changes should be transformed into enforcing the vocational training in companies and structural changes within the Slovak educational system.
\end{abstract}

Keywords: human resources management, labor market, skills, knowledge, education contents changes, job structure changes, education of employees, organisations operating, Slovakia.

JEL Classification: F63, F66, I25.

\section{Introduction}

Generally speaking, it will not be possible to manage the change of orientation to a new profession in a few weeks, retraining may take a year. Great attention will have to be paid to pre-school education so that talents from socially weaker backgrounds can be captured in time and they will be able to develop their talent and become a qualified required workforce. According to Křečková et al. (2016) and Toth et al. (2020) education will change significantly, new approaches and forms will be necessary and will be significantly more challenging for teachers. It is known that teachers do not have the required skills to be able to develop their students' digital skills in particular. Even we can see that the Covid 19 pandemic has significantly advanced education several years ahead within the use of online teaching methods in a relatively short time. Gärtner et al. (2017) and Jeníček (2016) concede that it turns out that those forms will need to be developed and used, but a combination with contact teaching will be still necessary, as social contact between students and teachers is very important. This fact affected the education system and moved it to the online space, which will have already been experienced by teachers and students, hence opening up space for changes in education system. Grmelová (2019a) and Mura et al. (2017) declare that the implementation of Industry 4.0 concept will significantly change the structure of labor market within the area of labor demand. However, the supply of labor will not be flexible enough, as it will encounter the problem of preparing workforce for the needs of labor market. New skills and competencies will be needed, so the skills of workforce will have to be shifted in a whole new direction. That's why the paper offers an attempt to figure out a kind of synergy between the necessary education system changes within the Industry 4.0 concept implementation.

The purpose of the paper is to analyze the impact of education system in Slovak Republic and Industry 4.0

${ }^{*}$ Corresponding author. E-mail: valna@ktu.lt 
within the new jobs creation issue. In individual parts of this study, the attributes will be analyzed to clarify the concept of Industry 4.0 in describing what its essence is, being the main objective of these issues. The importance will also be paid to the implementation of Industry 4.0 in Slovak industry sector and its development on labor market. The impact was measured by a questionnaire survey, out of which 220 responses were received being considered as a sufficient number to meet the paper's goal. Based on available information and data obtained from executed questionnaire survey, the situation on Slovak labor market, employers' problems related to the insufficient number of qualified labor force in industry sector, its possible replacement by automation and robotic technology will be analyzed. Specifically, the novelty lies in the issue to explore the possibilities in what way the Industry 4.0 will influence the labor market in industry sector in Slovakia and we will try to find out how the qualified structure of labor force within the Industry 4.0 implementation could be used in industry sector. As research limitation there can be mentioned issues such as: some questioners from the survey had to be void, some answers were not relevant, statistical data varies depending on the source being used, each organization has different approach how to process data and information thus comparison may not be too accurate.

\section{Literature review}

According to Hnát and Sankot (2019) and Okręglicka et al. (2017) the proponents of Industry 4.0 expect that the optimized features and processes of a medium sized enterprise lead to increasing revenue by several million dollars a year. An example of positive effects of digitization and robotics is Siemens, which has increased its production sevenfold through the implementation of Industry 4.0 concept and achieved $99.9966 \%$ accuracy in production processes, a world record for comparable companies (Cihelková et al., 2020; Miklosik et al. 2019).

Authors such as Sejkora and Sanko (2017), Šmejkal and Šaroch (2014) and Taušer and Čajka (2014) concede that many specialized job positions are currently being created and this trend will continue, however in the future it will be mainly the production of personalized products and services according to customer requirements. Maitah and Smutka (2019) state that automation transforms the work and skills needed for work, as a result of which the demand for advanced cognitive abilities and socio-behavioral skills increase. Skills associated with "adaptability" are increasingly desirable. This combination of specific cognitive abilities (critical thinking and problem solving) and socio-behavioral skills (creativity and curiosity) are transferable across different jobs (Sadílek \& Zadražilová, 2016; Kreckova et al., 2012). Miklosik et al. (2019) concur that it depends on how countries cope with the demand for changing job skills and how quickly the supply of skills changes. However, Mura and Ključnikov (2018) dispute that education systems tend to resist a change. A significant part of the adjustment of skills supply takes place outside the compulsory education and formal employment such as non-childhood education, tertiary education and adult education. Innovation creates new types of jobs. A large proportion of children entering elementary school in 2019 will work in occupations that do not exist now (Nencková et al., 2020; Sauer \& Prasek, 2018).

Cepel et al. (2019) and Boksa et al. (2020) declare that demand for people trained in technical and science disciplines is expected to increase significantly, but it is relatively difficult to predict whether this will really be the case. Zagata et al. (2019) indicate that rather, it will be a combination of knowledge and skills from different disciplines. Basic knowledge will include information retrieval and orientation in Big Data, control of communication technologies, communication skills and others. Problematic is the fact that at present we cannot define what type of job positions will be created, and therefore we cannot define what requirements will be placed on the workforce, we rely only on partial knowledge (Lipkova \& Hovorkova, 2018; De Castro et al., 2017). However, Gorlevskaya et al. (2018) and Daňo et al. (2020) reason that many schools and educational institutions already lack an effective curriculum to prepare people for the needs of labor market. Just as there were no professions such as web application programmer 25 years ago, and today it is a common job, it can be assumed that this trend will continue. Grmelová (2019b) declares that it will be necessary to respond to the change in the structure of professions by reforming the content and form of education. It will be important to reform not only the school system but also the lifelong learning system. Obadi and Korcek (2018) and Smutka et al. (2019) assert that in the long run, about one-fifth of current employees are expected to change their profession or job as a result of digitalization. As new jobs will be created for the implementation of Industry 4.0 concept, employers will require new, especially digital skills and abilities from employees. Šauer et al. (2019) and Grančay and Dudás (2019) indicate that there is a need to change teaching in secondary schools and, instead of narrowly being specialized in one area, the focus should be on a much broader overview, as people need to be educated in systemic and interdisciplinary thinking within all types of schools, including non-technical ones. Schwab (2018) and Roškot et al. (2020) argue that Industry 4.0 does not consider the main risk of job losses, but the fact that the changes and the resulting consequences will not be captured in time. It is necessary to focus not only on industry, but also on services, such as self-service cash registers or internet banking, which no longer require manual manpower (Helísek, 2019). Tajtáková et al. (2019) concur that newly profiled professions are expected to emerge for the collection, storage and use of specialized knowledge, but not everyone has the intellect to perform the job of, for example, the $3 \mathrm{D}$ operator or programmer.

In low- and middle-income countries, many people are employed, which did not exist three decades ago. India has almost 4 million application developers; Uganda has more than 400,000 internationally certified organic 
farmers and China has 100,000 data processors (Fojtíková, 2017; Piha et al., 2018). Dano and Lesakova (2018) and Grmelová (2020) state that meanwhile, many current jobs are changing into new forms, leading to new and sometimes unexpected combinations of skills. Trends in developed countries point out to job polarization - the expansion of high- and low-skilled jobs combined with a decline in medium-term jobs. According to Cihelková et al. (2019) and Zemanová (2015) there is a growing demand for workers who can perform untrained cognitive tasks, such as highly qualified research. There is also a growing demand for workers who are able to handle nonroutine tasks. Conversely, the demand for staff for routine procedural tasks, which are often performed in intermediate tasks such as data entry, is declining as these tasks are automated. Gress et al. (2016) and Sauer et al. (2018) affirm that the spectrum of skills is likely to be driven by the competitive forces of automation and globalization. The rate of technology take-up usually varies significantly from one developing country to another, and hence labor requirements. The learning at early childhood age is beginning to be considered a significant issue.

According to Sadílek and Zadražilová (2015) and Taušer et al. (2015) in France and other EU countries, the age of compulsory schooling is to be reduced from 6 to 3 years. This reform is designed to promote equality, hence helping to improve the ability of children from disadvantaged backgrounds to become competitive in education system. The most effective way to gain the skills required by changing the nature of work is to start early. Šaroch (2015) and Zagata et al. (2020) state that the first investments in nutrition, health, social affairs, education laid a strong foundation for the future acquisition of cognitive and socio-behavioral skills. These foundations will also enable the acquisition of future skills that will be important for increased resilience to stress from uncertainty. Hnát et al. (2016) and Svacina et al. (2018) agree that investing into education in early childhood is an important way to improve equal opportunities. At present, these investments are underestimated, especially for poor disadvantaged children, where a large part of talent is lost due to the unavailability of quality education and motivation to learn. Bohac and Lipkova (2016) and Thivant and Machková (2017) concede that the priority of these investments could pay off significantly for economies if both the approach and the quality of output are emphasized. Belás et al. (2016) and Grmanová and Ivanová (2018) concur that prenatal development up to the age of 5 is an important stage in the development of cognitive and sociobehavioral skills. During this period, the brain's ability to learn from experience is at its highest level. Experience and learning during this period directly affect results in adulthood. If this period is wasted, building skills becomes more and more difficult. Quality early childhood development programs enable children to learn. Investments in nutrition, health and stimulation during the first thousand days of life affect the development of stronger brains (Miklošík et al., 2016; Simionescu et al., 2019).
Generally speaking, the changing nature of work increases the attractiveness of tertiary education in several ways. Firstly, according to Lipkova et al. (2017) the demand for technology and integration has increased for general higher-level cognitive skills such as complex problem solving, critical thinking, and advanced communication which are transferable across jobs but cannot be acquired just by training. The growing demand for these skills has increased the salary of graduates. On the other hand, it brought a reduction in demand for less educated workers. Secondly, Fojtikova and Stanickova (2017) declare that tertiary education increases the demand for lifelong learning. Workers are expected to have multiple careers, not just more jobs during their lifetime. Tertiary education, with the wide range of opportunities being offered, will put pressure on universities, forcing them to meet this growing demand. Finally, Machkova and Sato (2017) affirm that tertiary education, especially universities, are becoming more attractive in a changing world of labor by becoming a platform for innovation. Skills acquisition is more and more a continuum, not a final, unchanging path.

\section{Research goal and methodology}

It turns out that education as we know it today must significantly change its character. It will be important for the workforce to be able to work with big data, to be able to quickly find the necessary information and then apply it in practice. The rapid changes brought by the development of communication technologies cannot be predicted and therefore the questions of how to educate and what to educate become fundamental topics of various discussions. The main goal of the presented study is, based on the performed analysis, to identify the areas on which the content of education should be focused in the future in relation to Industry 4.0. As a research method, in 2019 in the months of February June, a questionnaire survey in Slovak companies was conducted; 350 companies were contacted, and 220 responses were received being considered as a sufficient number to meet the paper's goal. The survey was conducted at random by Alexander Dubček University students and the answers were provided by the owners or HR managers in surveyed companies. The questionnaire survey was focused on the impact of Industry 4.0 on job creation. The contacts for companies were obtained from publicly available sources and databases lists such as websites of professional associations and interest groups. The respondents were selected from the following sources:

- the Association of Employers' Unions and Associations of Slovak Republic at http://www.azzz.sk/o-nas/ clenovia/;

- the Association of Automotive Industry available at: https://www.zapsr.sk/about/clenovia/;

- Databases of the web portal - finstat.sk;

- Personally known industry managers. 
While processing the questionnaires, the often used breakdown criterion was according to the size of a company. To be clear, the criteria for a micro-enterprise, a small enterprise, a medium-sized enterprise and a large enterprise were defined according to the breakdown of the Statistical Office of Slovak Republic as follows:

- enterprises up to 9 employees - micro-enterprise,

- businesses from 10-49 - small business,

- enterprises from 50-249 - medium enterprise,

- enterprises from 250 employees - large company.

In this breakdown for simplification, we did not take into account the turnover of a company, also because the research was focused on anticipated changes in the number and qualifications of workers in enterprises. We contacted 350 industrial companies. 220 companies provided us with answers to the questionnaire. We processed the results using statistical methods. In the following chapter, we present the results concerning the training of workforce in Slovak companies.

\section{Research results}

Changes related to the Industry 4.0 concept implementation should have a positive effect on increasing the competitiveness of companies, increasing the production flexibility, i.e. generally gaining a better position of companies on market as a result of higher efficiency of processes in companies. The expected positive changes should be transformed into higher productivity, bigger flexibility, higher competitiveness and profitability, security and ecology. For the above reasons, the reasons were assessed that motivate Slovak companies to implement the Industry 4.0 concept with the questionnaire question: What is the main reason for implementing the intelligent industry elements in your company? The results are presented in Figure 1.

The findings in Figure 1 show that labor productivity increase, the quality of products or services increase, labor shortage and replacing the human labor with technology are the most common reasons for implementing the Industry 4.0 concept. Initially, experts believed that the most important thing would be to replace human labor with technology, but this assumption has not been proved to be the main reason, but rather labor productivity increase. Although it should be noted that employers basically do not know what new technologies will bring in the future; currently during the COVID-19 pandemic crisis we can see huge progress, especially in online products sales. This trend will continue, moreover, we believe that the final product personalization will get significant attention in the next phase. Although many changes were expected,

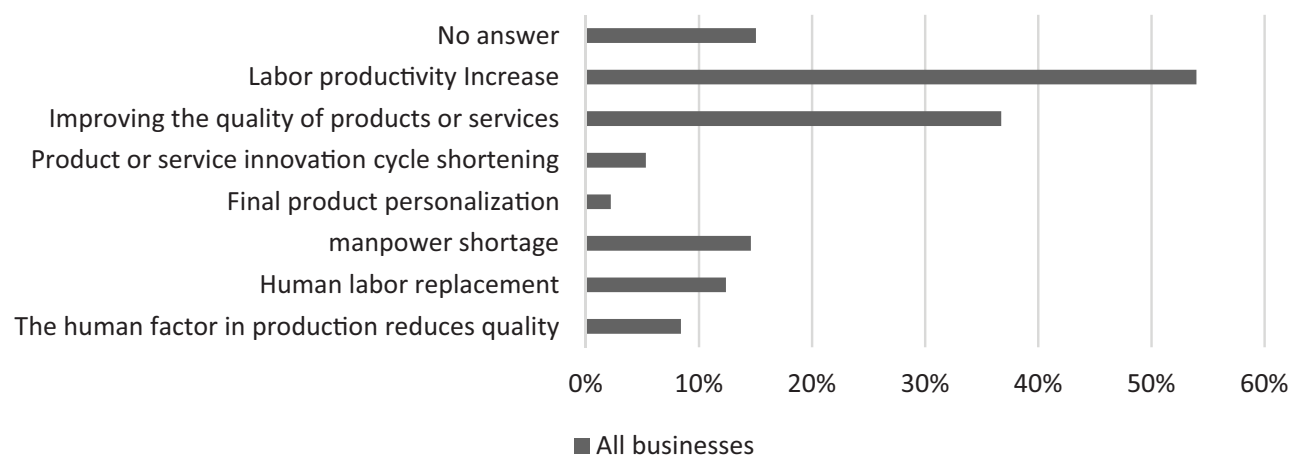

Figure 1. Reasons for Industry 4.0 elements implementation in a company

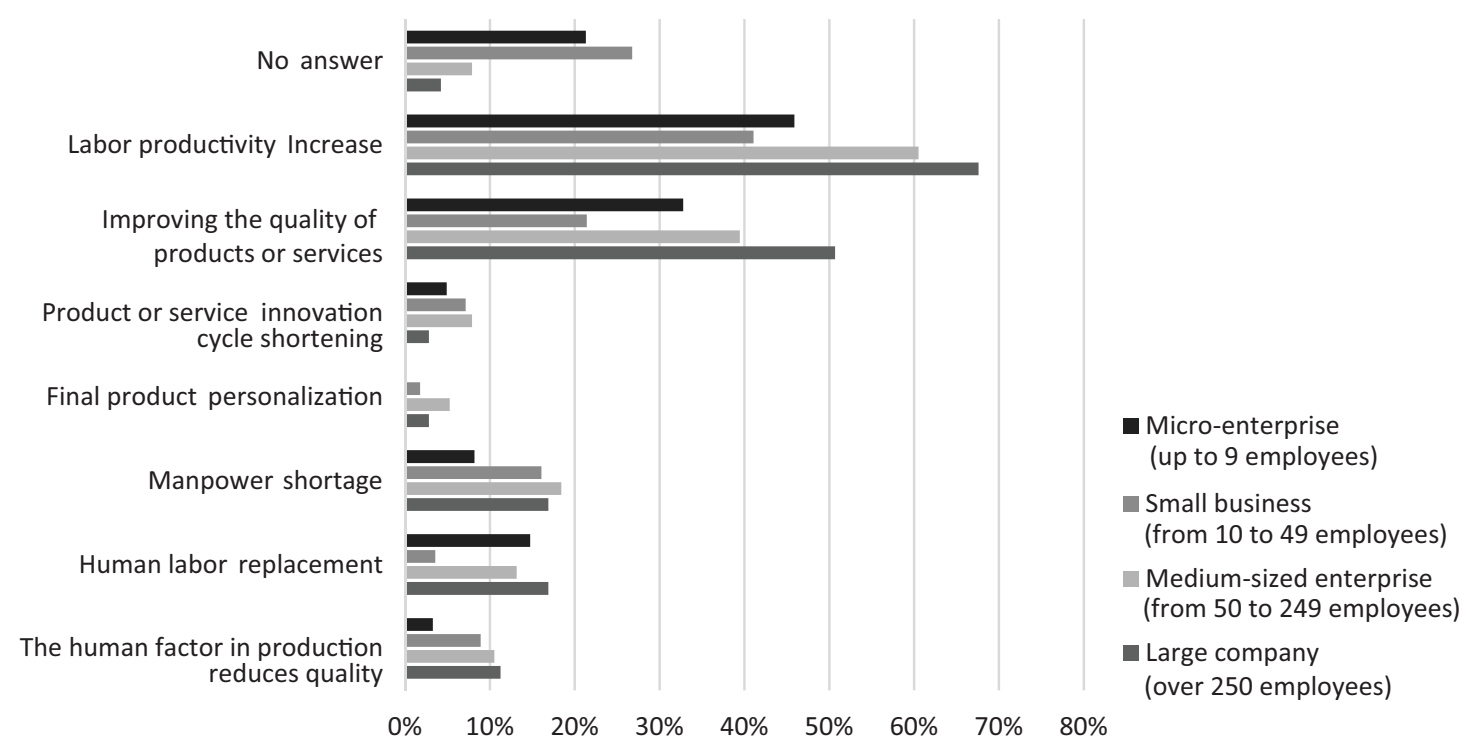

Figure 2. Main reasons for implementation of smart industry elements by the size of enterprise 
for instance, the ongoing corona virus (COVID-19) pandemic will significantly accelerate the implementation of Industry 4.0 concept (smart quarantine). In Figure 2, answers regarding the size of companies are presented. This is a more detailed expression regarding the expectations of particular companies.

From the results in Figure 2, it can be concluded that a necessary precondition to meet the goals within the Industry 4.0 concept is a change in workforce training. An important factor in improving the educational process at all levels will be the involvement of large companies and industries through their know-how, knowledge capacities and resources. The way and focus of education will significantly affect the preparation of workforce for the needs of employers. It is well known that the school system in its current form is not flexible enough to adapt to the needs of labor market. Next it was interested, what the content of education should be affected by, this time, from the point of view of employers - the results are shown in Figure 3. The question was stayed: The new content of education in terms of Industry 4.0 should refer to following areas?

It is clear from the answers in Figure 3 that employers require mainly technical skills and specialization in study field. This is very contradictory, because we do not know the content of jobs being created, so in our opinion it will be far more important to focus on general knowledge and education. in specialization will be more shifted to employers. It is expected that there will be much more specializations than it has been the case so far and it will not be possible to meet these requirements in formal education system. The survey points out quite strongly to the need for education in communication skills and teamwork. Figure 4 shows the answers regarding the new content of education according to the size of enterprises.

From the Figure 4 it can be seen that the size of a company affects the training requirements. Of course, small and medium-sized companies also prefer technical skills, but they prefer a general knowledge unlike large companies. The employee in a small and medium-sized company must be more flexible and therefore such a content

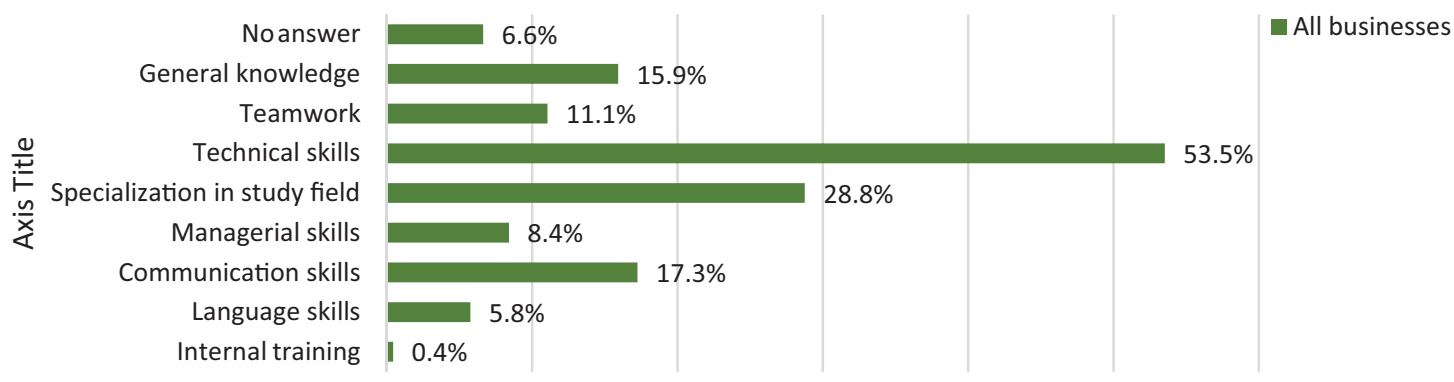

Figure 3. New areas of education within the Industry 4.0

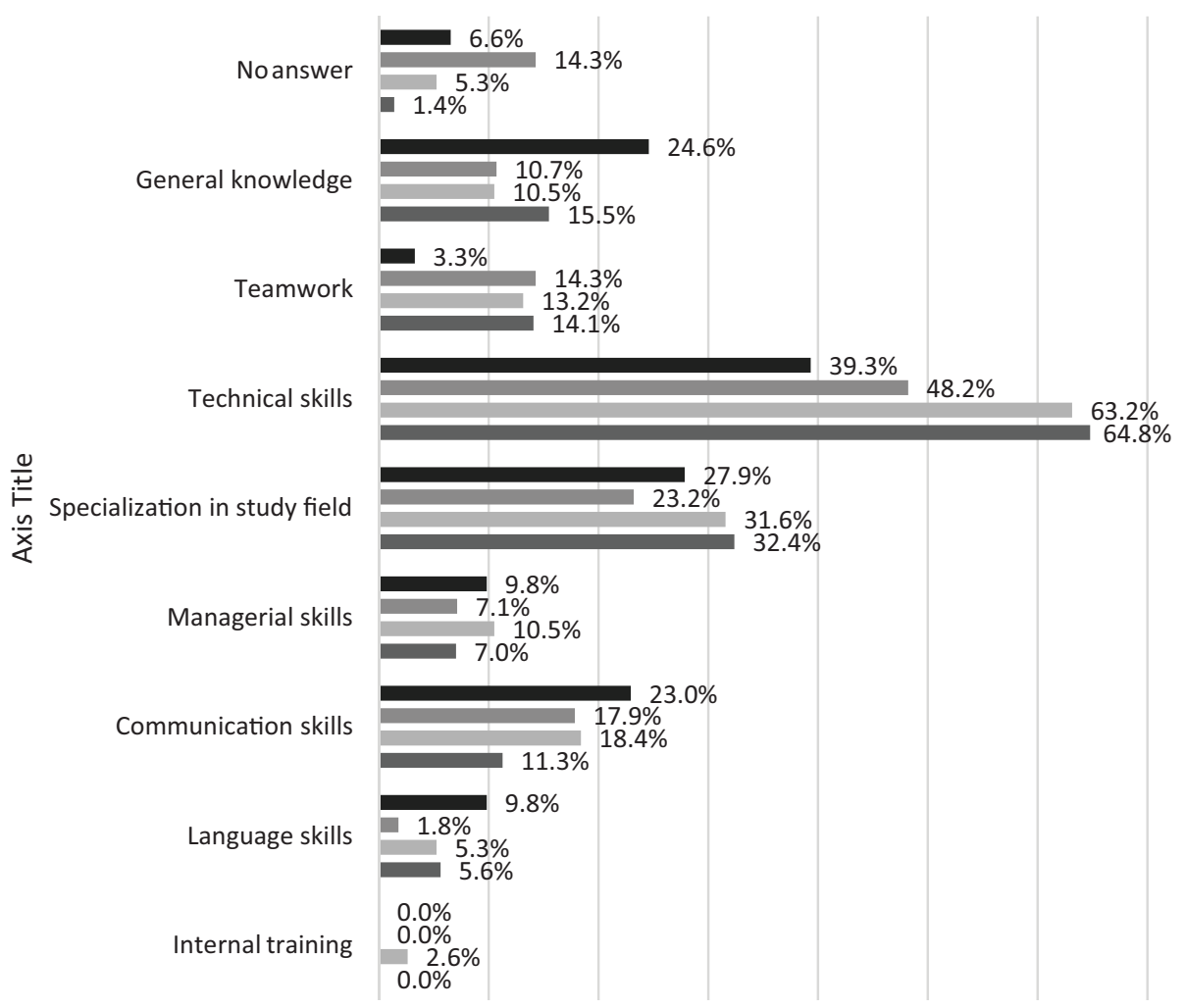

Figure 4 . New areas of education within the Industry 4.0 by the size of enterprise 
of education can be more beneficial. Interesting finding is that internal training is not preferred at all by SMEs. However, employers will have to reorient themselves far more to training their employees in their premises, it will be specific knowledge and skills that will not be possible to learn in the education system. Figure 5 shows employers' answers to the question regarding the availability of workforce on labor market. There is a clear labor shortage visible in large and medium-sized enterprises; microenterprises have not yet clearly felt a shortage of labor in 2019.

Based on data results from Figure 5, it can be concluded that the nature of projects in Industry 4.0 is characterized by short development periods. This does not mean that businesses should not take expectations into account in the long run, as the pace of change in technological, social, economic and political environment is getting faster and faster. Businesses should get used to innovation process adaption. The innovation process should become their routine, being achieved by developing the innovative work, behavior and strengthening management practices in organization, what can positively affect innovation. Figure 6 presents the results of a survey on the issue of changing job requirements according to the size of enterprises based on the stated question: As a result of new technologies implementation, do you expect changes in the requirements for job holders?

In Figure 6, the answers from the companies where we contacted the survey show that individual companies are starting to be aware of the changes that will affect them, but they are not yet able to define exactly to what extent these changes will affect them. The findings show that large enterprises anticipate an increased need for highly skilled workers from external sources, while small and medium-sized enterprises are interested in replacing specialized workers from internal sources by retraining their own low-skilled workforce.

\section{Discussion}

Based on the findings, in the following section the issue regarding the identification of areas on which the content

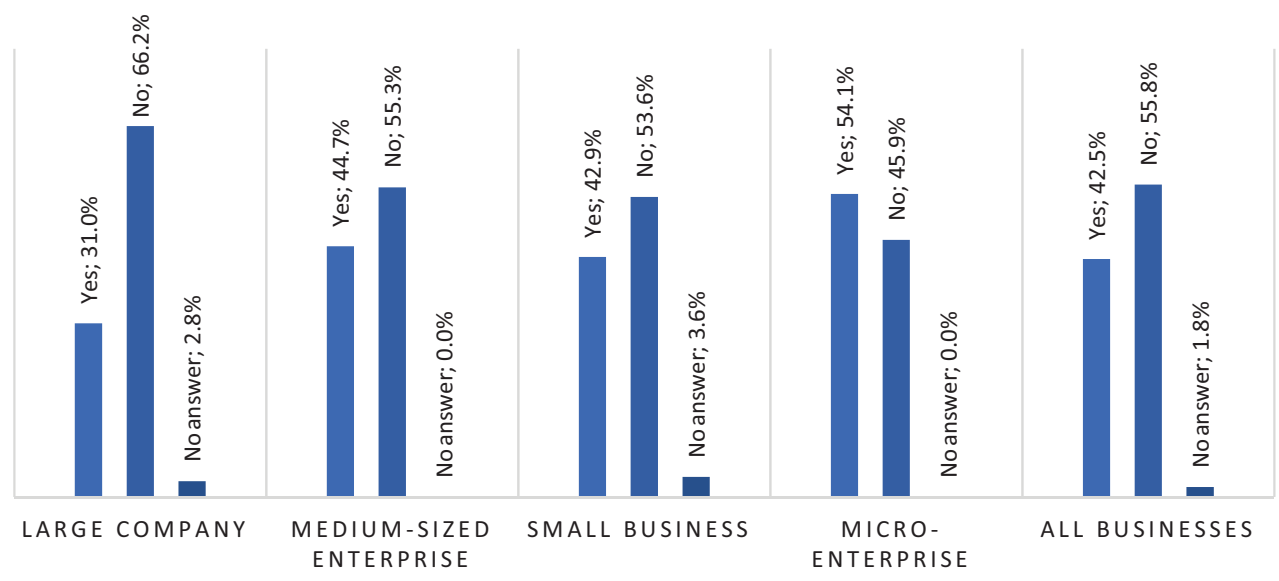

Figure 5. The degree of labor force availability on labor market by the size of enterprise

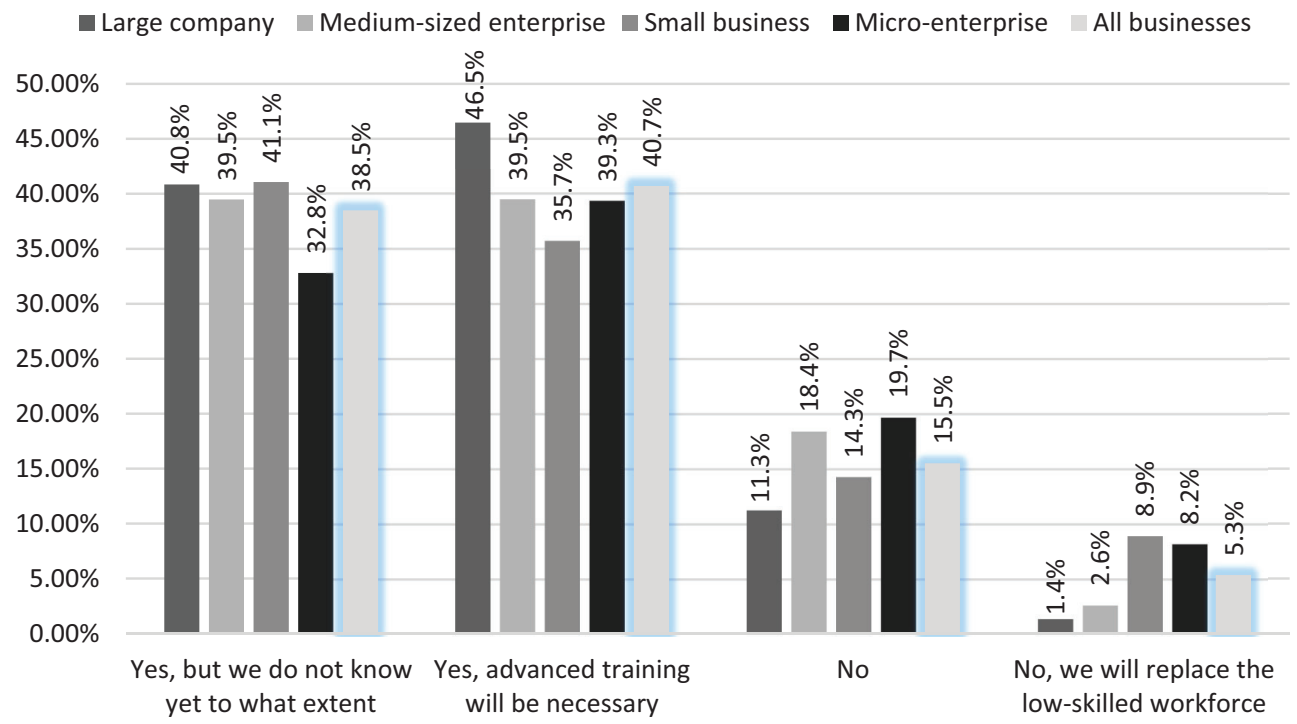

Figure 6. Changing job requirements by the size of enterprise 
of education should be focused on in the future in relation to Industry 4.0 will be discussed. Generally speaking, at present times, the term fourth industrial revolution or the fourth phase of industrial revolution called Industry 4.0 is becoming more and more common. According to the authors such as Mentlík and Helísek (2018) it is a process of digitization of production processes, products, services and equipment, but also applications of exponential technologies. Industry 4.0 is based on the interconnectedness and communication of people, devices and machines with each other so that all previously untapped information is to be fully utilized. This connection increases the efficiency of machines and equipment, also reduces costs and saves resources. By digitizing the companies can gain intelligent tracking and constant overview thanks to transparent processes that will enable them to react quickly and flexibly to possible changes on markets. From the findings brought by our survey it can be implied that workforce training is a serious topic today. The main problem is that we cannot define what jobs will be created as new ones, so we cannot define the requirements for the holders of these jobs. As a result of automation, it was assumed that jobs in production processes in particular would disappear, but as it turns out with the entry of communication technologies and their development to the same intensity, some jobs will also disappear in the field of services. Navickas et al. (2017) indicate that the biggest boom is, for example, in tourism, where tickets and accommodation are ordered online and the final product is personalized according to the customer's wishes. The second area where we can see changes is banking, where communication with the client begins to lead artificial intelligence, as well as commerce and trade segment is experiencing a significant boom in online sales.

It can be assumed that regarding the concept of intelligent industry development in the conditions of Slovak Republic under the responsibility of the Ministry of Economy of Slovak Republic (ME SR) being focused on education, a package of steps leading to a change in education system has been presented. According to the ME $\mathrm{SR}$, one of the recommendations is to create innovative state educational programs for study and teaching fields at all levels of education. In order to address the lack of expertise in specific areas and to adapt the education system to the reality in the present and the future, there is a must to put new education content with highly specialized skills at the forefront of education at all levels, such as robotics, automation, information and technology deployment, open data, programming, artificial intelligence, security and protection of privacy, digital skills, STEM subjects (science, technology, engineering, mathematics), creative design and so on. Emphasis should be put on applied informatics with practical use, for example in the field of information technology (IT), data processing, data mining, etc. The ME SR declare that the change in education system in Slovakia will have to include a change in teaching methods, procedures and curricula made by universities and teachers. That means it is essential that pedagogical staff at all levels of education must adapt to technological trends. The study of computer science teaching must examine new trends and appropriate teaching methodologies for new trends, especially with the use of creativity, constructivism and research approach. The use of open information technologies in education and the use of public licenses for educational resources should become a standard. As further stated by the Ministry of Economy of Slovak Republic, in the development concept at present times, an effort is already underway to restore the so-called dual education, the aim of which is to enable students to work in parallel in factories (or other types of companies) during their studies, hence increasing the practical teaching of individual professions. Another goal should be to interlink the educational institutions, especially secondary schools, colleges and universities, with businesses and industry into so-called clusters (Srovnalíková et al., 2018). It will be necessary to increase the flexibility of curriculum content with regard to the dynamically changing requirements of employers.

Needless to say that in any company where running the Industry 4.0 concept implementation the task of human resources should be an issue that employees in all jobs, including business owners, are supposed to take technological change as a challenge and are prepared to adapt to changing rules in the shortest possible time. In the factories of future, the need for digital work skills will increase on account of manual skills. The role of smart factories in the future will be to provide the exact information necessary to employees in real time or in certain specific situations in order to perform their job responsibilities as efficiently as possible. Many authors such as Jiránková (2012), Grmelová and Zahradníková (2019) and Toth et al. (2019) argue that workers will be able to control and supervise the entire production process from the table through analyzes carried out through intelligent devices that monitor all processes in production. Intelligent devices integrated into a single system allow employees to make competent decisions in a very short time. The implementation of collaborative robots in the performance of work activities carried out by human beings can help traditional workers, especially in the performance of occupations that negatively affect the ergonomic structure of an individual. Intelligent tools and technologies will become increasingly autonomous and automated in the future, which means, on one hand, that more and more monotonous and repetitive activities performed by people will be replaced, but on the other hand the significance of supervising machines will enhance the opportunities to increase and invest into human capital and make a shift from lower value-added to higher value-added labor structure (Zagata et al., 2019; Zemanová, 2015).

It can be noticed that however, the main emphasis will be put on the creative way of individual and innovative thinking lifelong learning will become important. It is obvious that digital technologies are responsible for the need 
to re-evaluate the goals of education and change the longstanding practices in Slovak educational system. If Slovakia wants to be a competitive and open economy in Europe, it is necessary to equip elementary school students with skills and knowledge in the field of IT, which will help them to strengthen the development of IT sector. We can highlight that the concept of computer thinking has become a phenomenon today, which explains the importance of understanding the world around us from a different, new perspective. It is about new information and the new ways in which digital technologies work. It is a way of thinking with the use of computer methods to solve problem, such as those that are solvable, but also vaguely specified. The inclusion of computer science will help in the formulation and structuring of more advanced educational goals as a result of which students acquire skills that will help with problem solving. Informatics should be included as a full-fledged subject along with other subjects with important links. Many teachers in Slovakia perceive the use of digital technologies as a necessity and are interested in integrating them into teaching plans.

\section{Conclusions}

The main goal of the paper was to analyze the impact of education system in Slovak Republic and Industry 4.0 within the new jobs creation issue and the task was to identify the areas on which the content of education should be focused in the future in relation to Industry 4.0. In this paper we have shown that to understand the overall modernization of education, it is necessary to look into the spheres of production and new technologies, which students should be partially prepared for as potential employees. Along with the implementation of new technologies, it will be necessary to employ a big number of experts. This will create new jobs and reduce unemployment, but still dispose a large number of lowskilled workers. It will be a huge challenge for people to find new jobs. We have arrived to the conclusion that one possible way how to solve this issue is to increase education through retraining courses, which will bring people new opportunities. In modern education, great emphasis is placed on the quality of teachers and their abilities. It is important that they are able to adapt to new conditions, and be open to the means available to support the teaching of their students. Such a system should ensure the education and motivation of the active human being to be ready to overcome the obstacles that will be necessary to be faced to in the future.

Finally, to sum up, the labor supply will not be flexible enough, as it will encounter the problem of preparing the workforce for the labor market needs. New skills and competencies will be necessary, so the skills of the workforce will have to be moved in a whole new direction. Demand for people trained in technical and science disciplines is expected to increase significantly, but it is relatively difficult to predict whether this will really be the case. Rather, it will be a combination of knowledge and skills from different disciplines. It will be important for the workforce to be able to work with big data, to be able to quickly find the necessary information and then apply it in practice. The rapid changes brought by the development of communication technologies cannot be predicted and therefore the questions of how to educate and what to educate is becoming a big issue of various discussions. Further research will be devoted to exploring the role of Industry 4.0 and its impact on industry sector within the world economy development particularly in the U.S. and EU economies with implications on their labor market and social and economic development.

\section{Funding}

This paper was supported by the Slovak Ministry of Education's Scientific grant agency VEGA: “The impact of Industry 4.0 on jobs structure changes". Project registration number: [Reg. No.: 1/0430/18].

This paper was supported by the Slovak Ministry of Education's Scientific grant agency VEGA: “Assessment changes in the qualitative structure of international economic relations under the influence of Industry 4.0 with implications for the EU and Slovak economic policies". Project registration number: [Reg. No.: 1/0462/20].

\section{Author contributions}

Conceptualization: AG, MK; Data curation: AG, MK; Formal analysis: AG, MK, VN; Funding acquisition: AG, MK; Investigation: AG, MK, VN; Methodology: AG, MK, VN; Project administration: AG, MK; Resources: MK; Software: MK; Supervision: AG, VN; Validation: VN; Visualization: MK; Writing - original draft: AG, MK, VN; Writing - review \& editing: $\mathrm{MK}, \mathrm{VN}$.

\section{Disclosure statement}

Authors of this article declare they do not have any competing financial, professional, or personal interests from other parties.

\section{References}

Automotive Industry Association of the Slovak Republic. (2020). https://www.zapsr.sk/about/clenovia/

Belás, J., Vojtovič, S., \& Ključnikov, A. (2016). Microenterprises and significant risk factors in loan process. Economics and Sociology, 9(1), 43-59. https://doi.org/10.14254/2071-789X.2016/9-1/3

Bohac, R., \& Lipkova, L. (2016). Cataracts of globalization and the economic diplomacy of small states. Economic AnnalsXXI, 159(5-6), 16-19. https://doi.org/10.21003/ea.V159-03

Boksa, M., Saroch, S., \& Boksova, J. (2020). Digitalization of SMEs. International Advances in Economic Research, 26(2), 175-177. https://doi.org/10.1007/s11294-020-09777-1

Cepel, M., Belas, J., Rozsa, Z., \& Strnad, Z. (2019). Selected economic factors of the quality of business environment. Journal of International Studies, 12(2), 228-240.

https://doi.org/10.14254/2071-8330.2019/12-2/14 
Cihelková, E., Nguyen, H. P., Fabuš, M., \& Čimová, K. (2020). The EU concept of the "strategic partnership": Identifying the "unifying" criteria for the differentiation of strategic partners. Entrepreneurship and Sustainability Issues, 7(3), 1723-1739. https://doi.org/10.9770/jesi.2020.7.3(19)

Cihelková, E., Platonova, I. N., \& Frolova, E. D. (2019). Comparative analysis of supporting small and medium enterprises for enhancing created added value in the EU and China. Economy of Region, 15(1), 256-269. https://doi.org/10.17059/2019-1-20

Daňo, F., Drábik, P., \& Hanuláková, E. (2020). Circular business models in textiles and apparel sector in Slovakia. Central European Business Review, 9(1), 1-19.

https://doi.org/10.18267/j.cebr.226

Dano, F., \& Lesakova, D. (2018). The role of environmental stimuli in shopping evaluation and responses, Ekonomicky Casopis, 66(5), 465-478.

De Castro, T., Vlčková, J., \& Hnát, P. (2017). Trade and investment relations between the Czech Republic and China: The Czech Republic as a gateway to the EU? Society and Economy, 39(4), 481-499. https://doi.org/10.1556/204.2017.39.4.2

Federation of employers' associations of the Slovak Republic. (2020). https://www.azzz.sk/o-nas/clenovia/

FinStat s. r. o. (2020). https://finstat.sk

Fojtíková, L. (2017). China's trade competitiveness in the steel industry after 15 years of its membership in the WTO. Economic Annals-XXI, 166(7-8), 16-19.

https://doi.org/10.21003/ea.V166-03

Fojtikova, L., \& Stanickova, M. (2017). The EU member states export competitiveness and productivity. Politicka Ekonomie, 65(6), 669-689. https://doi.org/10.18267/j.polek.1169

Gärtner, M., Sadílek, T., \& Zadražilová, D. (2017). Cross-cultural adaptability in a sample of international university students in Prague - gender and culture effect. Journal of Applied Economic Sciences, 12(3), 893-906.

Gorlevskaya, L., Kubičková, V., Fodranová, I., \& Žák, Š. (2018). Innovations and new product development: Evidence from enterprises active in Slovak Republic. Journal of Applied Economic Sciences, 13(1), 164-173.

Grančay, M., \& Dudáš, T. (2019). Bilateral trade flows and comparative advantage: Does the size matter? Society and Economy, 41(4), 397-413. https://doi.org/10.1556/204.2019.013

Gress, M., Lipkova, L., \& Harakal'ova, L. (2016). EU enlargement 2004 - Ten years after. Actual Problems of Economics, 177(3), 23-30.

Grmanová, E., \& Ivanová, E. (2018). Efficiency of banks in Slovakia: Measuring by DEA models. Journal of International Studies, 11(1), 257-272.

https://doi.org/10.14254/2071-8330.2018/11-1/20

Grmelová, N. (2020). Czech Republic: Opposing mandatory front of package food labelling in the council preliminary discussions. European Food and Feed Law Review, 15(5), 477-479.

Grmelová, N. (2019a). Czech Republic: Cross-compliance criteria for farming and processing edible insects. European Food and Feed Law Review, 14(1), 61-65.

Grmelová, N. (2019b). Czech Republic: Key topics discussed at the central Europe food waste conference 2019. European Food and Feed Law Review, 14(4), 380-382.

Grmelová, N., \& Zahradníková, R. (2019). Corporate social responsibility of five leading food retailers operating in the Czech Republic. European Food and Feed Law Review, 14(2), 180-186.

Helísek, M. (2019). Exchange rate mechanism II and the risk of currency crisis - Empiricism and theory. Journal of International Studies, 12(1), 297-312.

https://doi.org/10.14254/2071-8330.2019/12-1/20
Hnát, P., \& Sankot, O. (2019). European imbalances and shifts of global value chains to the Central European periphery: Role of institutions. Acta Universitatis Carolinae, Geographica, 54(2), 221-231.

https://doi.org/10.14712/23361980.2019.19

Hnát, P., Zemanová, Š., \& Machoň, M. (2016). Economics-focused articles in the journal mezinárodní vztahy as a reflection of the specifics of Czech research [Ekonomicky zaměřené texty v časopise Mezinárodní vztahy jako odraz specifik českého výzkumu]. Mezinarodni Vztahy, 51(1), 68-82.

Jeníček, V. (2016). Economic growth in the development economy. Agricultural Economics (Czech Republic), 62(2), 93-99. https://doi.org/10.17221/234/2014-AGRICECON

Jiránková, M. (2012). Nation-states as investors in a globalized world. Ekonomicky Casopis, 60(8), 854-870.

Křečková, Z., Zadražilová, D., \& Řezanková, H. (2016). The added value of women in management: The Czech case. Prague Economic Papers, 25(3), 354-373. https://doi.org/10.18267/j.pep.588

Kreckova, Z., Odehnalova, J., \& Reardon, J. (2012). Consumer ethnocentricity within the environment of economic crisis [Vartotojo etnocentriškumas ekonominès krizès aplinkoje]. Engineering Economics, 23(3), 271-281. https://doi.org/10.5755/j01.ee.23.3.1932

Lipkova, L., Gress, M., \& Poncarova, A. (2017). Tax systems in the Czech Republic and the Slovak Republic: Comparison with an emphasis on income tax. Economic Annals-XXI, 165(5-6), 47-51. https://doi.org/10.21003/ea.V165-10

Lipkova, L., \& Hovorkova, K. (2018). Economic situation in Norway after the outbreak of the global financial and oil crises in the context of EU integration trends, Economic Annals-XXI, 169(1-2), 12-14. https://doi.org/10.21003/ea.V169-02

Machkova, H., \& Sato, A. (2017). Analysis of competitiveness of Belgian sugar industry. Listy Cukrovarnicke a Reparske, 133(12), 390-392.

Maitah, M., \& Smutka, L. (2019). The development of world sugar prices. Sugar Tech, 21(1). https://doi.org/10.1007/s12355-018-0618-y

Mentlík, R., \& Helísek, M. (2018). Euro and corporate management in Czech Republic. European Research Studies Journal, 21(2), 441-452. https://doi.org/10.35808/ersj/1013

Miklosik, A., Evans, N., Zak, S., \& Lipianska, J. (2019). A framework for constructing optimisation models to increase the visibility of organizations' information in search engines. Information Research, 24(1), article number 808.

Miklošík, A., Hlavatý, I., Daňo, F., \& Červenka, P. (2016). Google answer box keyword-related analysis a case study. European Journal of Science and Theology, 12(5), 185-194.

Miklosik, A., Kuchta, M., Evans, N., \& Zak, S. (2019). Towards the adoption of machine learning-based analytical tools in digital marketing. IEEE Access, 7, article number 8746184, 85705-85718. https://doi.org/10.1109/ACCESS.2019.2924425

Ministry of Economy of Slovak Republic. (2020). https://economy.gov.sk

Mura, L., Havierniková, K., \& Machová, R. (2017). Empirical results of entrepreneurs' network: Case study of Slovakia. Serbian Journal of Management, 12(1), 121-131. https://doi.org/10.5937/sjm12-10418

Mura, L., \& Ključnikov, A. (2018). Small businesses in rural tourism and agro tourism: Study from Slovakia. Economics and Sociology, 11(3), 286-300. https://doi.org/10.14254/2071-789X.2018/11-3/17

Navickas, V., Vojtovic, S., \& Svazas, M. (2017). Biomass clusters influence on business competitiveness [Wpływ klastra 
biomasy na konkurencyjność gospodarczą]. Polish Journal of Management Studies, 16(2), 188-197.

https://doi.org/10.17512/pjms.2017.16.2.16

Nencková, L., Pecáková, I., \& Šauer, P. (2020). Disposal behaviour of Czech consumers towards textile products. Waste Management, 106, 71-76.

https://doi.org/10.1016/j.wasman.2020.03.001

Obadi, S. M., \& Korcek, M. (2018). The crude oil price and speculations: Investigation using granger causality test. International Journal of Energy Economics and Policy, 8(3), 275-282.

Okręglicka, M., Havierniková, K., Mynarzová, M., \& LemańskaMajdzik, A. (2017). Entrepreneurial intention creation of students in Poland, Slovakia and Czechia [Kreowanie intencji przedsiębiorczych wśród studentów w Polsce, Słowacji i Czechach]. Polish Journal of Management Studies, 15(2), 162-172. https://doi.org/10.17512/pjms.2017.15.2.15

Piha, S., Pohjanheimo, T., Lähteenmäki-Uutela, A., Křečková, Z., \& Otterbring, T. (2018). The effects of consumer knowledge on the willingness to buy insect food: An exploratory crossregional study in Northern and Central Europe. Food Quality and Preference, 70, 1-10. https://doi.org/10.1016/j.foodqual.2016.12.006

Roškot, M., Wanasika, I., \& Kreckova Kroupova, Z. (2020). Cybercrime in Europe: surprising results of an expensive lapse. Journal of Business Strategy, (article in press). https://doi.org/10.1108/JBS-12-2019-0235

Sadílek, T., \& Zadražilová, D. (2015). History and current situation of sugar industry in Austria [Historie a současný stav cukrovarnictví v Rakousku]. Listy Cukrovarnicke a Reparske, 131(12), 392-395.

Sadílek, T., \& Zadražilová, D. (2016). Current trends in German sugar industry [Současné trendy německého cukrovarnictví]. Listy Cukrovarnicke a Reparske, 132(12), 390-393.

Sauer, P., \& Prasek, J. (2018). Private subject in wastewater treatment regional coalition project: The case of chemical industry factory. Journal of Environmental Protection and Ecology, 19(2), 499-507. https://doi.org/10.1504/IJETM.2018.100586

Sauer, P., Hadrabova, A., \& Kreuz, J. (2018). Decoupling of GDP and air pollution in the Czech Republic: Trend analysis and policy story behind. International Journal of Environmental Technology and Management, 21(5-6), 253-272.

Smutka, L., Maitah, M., \& Svatoš, M. (2019). Policy impacts on the EU-Russian trade performance: The case of agri-food trade. Journal of International Studies, 12(2), 82-98. https://doi.org/10.14254/2071-8330.2019/12-2/5

Schwab, K. (2018). The fourth industrial revolution. https://www.foreignaffairs.com/articles/2015-12-12/fourthindustrial-revolution

Sejkora, J. \& Sankot, O. (2017). Comparative advantage, economic structure and growth: The case of Senegal. South African Journal of Economic and Management Sciences, 20(1), article number a1685. https://doi.org/10.4102/sajems.v20i1.1685

Simionescu, M., Bilan, Y., Krajňáková, E., Streimikiene, D., \& Gędek, S. (2019). Renewable energy in the electricity sector and GDP per capita in the European Union. Energies, 12(13), article number 2520. https://doi.org/10.3390/en12132520

Srovnalíková, P., Havierniková, K., \& Guščinskiene, J. (2018). Assessment of reasons for being engaged in clusters in terms of sustainable development. Journal of Security and Sustainability Issues, 8(1), 103-112. https://doi.org/10.9770/jssi.2018.8.1(9)

Svacina, P., Rýdlová, B., \& Bohácek, M. (2018). Remuneration of employee inventions at Czech universities. Scientific Papers of the University of Pardubice, Series D: Faculty of Economics and Administration, 26(43), 232-245.

Šaroch, S. (2015). Informované zamyšlení nad budoucností EU (a nejen nad ní). Politicka Ekonomie, 63(5), 677-680. https://doi.org/10.18267/j.polek.1019

Šauer, P., Kolínský, O., \& Prášek, J. (2019). Negotiating municipalities-industrial factory wastewater treatment coalition project: An economic laboratory experiment. Journal of Environmental Protection and Ecology, 20(1), 369-375.

Šmejkal, V., \& Šaroch, S. (2014). EU as a highly competitive social market economy-Goal, Options, and reality. Review of Economic Perspectives, 14(4), 393-410.

https://doi.org/10.1515/revecp-2015-0006

Tajtáková, M., Žák, Š., \& Filo, P. (2019). The lipstick effect and outdoor cultural consumption in Slovakia in times of crisis. Ekonomicky Casopis, 67(6), 607-628.

Taušer, J., Arltová, M., \& Žamberský, P. (2015). Czech exports and German GDP: A closer look. Prague Economic Papers, 24(1), 17-37. https://doi.org/10.18267/j.pep.498

Taušer, J., \& Čajka, R. (2014). Hedging techniques in commodity risk management. Agricultural Economics (Czech Republic), 60(4), 174-182.

https://doi.org/10.17221/120/2013-AGRICECON

Thivant, E., \& Machková, H. (2017). An analysis of French mergers and acquisitions in different sectors of the Czech economy. Central European Business Review, 6(1), 48-60.

https://doi.org/10.18267/j.cebr.172

Toth, D., Maitah, M., \& Maitah, K. (2019). Development and forecast of employment in forestry in the Czech Republic. Sustainability (Switzerland), 11(24), article number 6901. https://doi.org/10.3390/su11246901

Toth, D., Maitah, M., Maitah, K., \& Jarolínová, V. (2020). The impacts of calamity logging on the development of spruce wood prices in Czech forestry. Forests, 11(3), article number 283. https://doi.org/10.3390/f11030283

Zagata, L., Hrabák, J., \& Lošták, M. (2020). Post-socialist transition as a driving force of the sustainable agriculture: a case study from the Czech Republic. Agroecology and Sustainable Food Systems, 44(2), 238-257. https://doi.org/10.1080/21683565.2019.1585400

Zagata, L., Lošták, M., \& Swain, N. (2019). Family farm succession of the first post-socialist generation in the Czech Republic. Eastern European Countryside, 25(1), 9-35.

Zemanová, Š., Druláková, R., Peterková, J., \& Přikryl, P. (2015). Foreign policy strategies of small states in contemporary international relations [Zahraničněpolitické strategie malých států v současném mezinárodním prostředí]. Mezinarodni Vztahy, 50(3), 5-23.

Zemanová, Š. (2015). When could new "potent small states" emerge? A study of the recent metamorphosis of Czech human rights foreign policy. Journal of International Relations and Development, 18(2), 129-154.

https://doi.org/10.1057/jird.2013.16 